2. Tarleton's problem:*

To get a solid of revolution on a given base with a given volume which shall experience a minimum resistance when it moves through a fluid in the direction of its axis.

The solution is a hypocycloid of three cusps. $\dagger$

3. Euler's problem: $\ddagger$

The full enunciation of this problem is found in Professor G. H. Light's paper in the July number of this Bulletin, 1918 , volume 24 , page 480 . The solution can be easily obtained in its parametrical form, which is quite the same as that for Tarleton's problem. So without using Professor Light's method, we may use Todhunter's method to show that the solution is a hypocycloid of three cusps. Todhunter's method depends on the relation

$$
d y / d x=p=\tan \phi,
$$

and seems to be more easy and more natural.

August, 1918.

\title{
NOTE ON EDITIONS OF VON STAUDT'S GEOMETRIE DER LAGE.
}

BY PROFESSOR R. C. ARCHIBALD

(1) The first editions of K. G. C. von Staudt's Geometrie der Lage (G.) and Beiträge zur Geometrie der Lage (B.) were issued in 4 parts, paper covers, by "Verlag von Bauer und Raspe (Julius Merz)," Nürnberg, 1847-1860,§ each of the four parts having a separate title page.

(2) An Italian translation of (G.), and of some paragraphs of (B.), was published in 1889.\|

* Philosophical Magazine, 4th series, vol. 34 (1867).

† See Todhunter's Researches in the Calculus of Variations, 1871, pp. 196-198. It is reproduced in Carll's Calculus of Variations, 1881, pp. 144146.

$\ddagger$ Scientia Navalis, Prop. 53.

$\S(\mathrm{G}$.): 1847 (on the reverse of the title page is: "Erlangen, gedruckt bei J. J. Barfus," pp. $6+216$ ). (B.): 1856 ("Druck von Junge \& Sohn in Erlangen,": pp. 6 + 130), 1857 ("Druck von Junge \& Sohn in Erlangen," pp. 131-284), 1860 ("Druck der A. E. Junge'schen Universitätsbuchdruckerei," pp. $6+285-396)$.

| Geometria di Posizione di Giorgio Carlo Cristiano v. Staudt. Traduzione dal tedesco a cura del dott. M. Pieri, professore all'Accademia militare, preceduta da una studio del Prof. C. Segre sulla vita e le opere del v. Staudt. Torino, Bocca, $28+233$ pp. 
These editions are well known. There was, however, (3) another German edition, which seems entirely to have escaped the notice of the bibliographer and historian.* A copy of this edition has been recently presented to Brown University. In it title pages are lacking for each of the three parts of (B.). While the title page of (G.) is without date, the place of publication is given: "Nürnberg, Verlag der Fr. Korn'schen Buchhandlung." $\dagger$

The total number of pages in each of the four parts is the same as in (1), and the "Berichtigungen," on pages 216 (G) and 283 (B.) are reprinted without corresponding changes in the text. While there is in general a one-to-one correspondence in the content of pages numbered the same in (1) and (3), this is not absolute; for example, in (G.): pages III, 9, and 203 (where a correction of the original has been made); and in (B.): pages $15,47,134-5$, and 187 . The print page of the new edition is slightly longer and narrower than that of the old one.

The only clue I could find as to the date of this edition was in the British Museum catalogue, volume SQ.-States of the Church, London, 1896) which lists (G.) as published in "Nürnberg, [1883]." On appealing to the Museum for its authority in determining the date "[1883]," Mr. Alfred W. Pollard, the erudite keeper in the Library wrote in part as follows: "Our copy of K. G. C. von Staudt's Geometrie der Lage (Nürnberg, Verlag der Fr. Kornschen Buchhandlung) cannot have been published later than 1883, as we paid for it on 6 July of that year, the invoice being dated 20 January. A young cataloguer (he came that June) cataloguing it in October assumed that it was a new book. I think it was really published between 1877 and 1880. On the cover it advertises an Atlascommentar of G. Wenz which I find in Heinsius dated 1877. It also advertises Dr. L. Wöckel's Geometrie der Alten in einer Sammlung von 850 Aufgaben. This number 850 occurs in the eighth and ninth editions (published by Bauer and Raspe 1869 and 1871) and in the tenth and eleventh (published by

* For example: Poggendorff, Kayser (Bücher-Lexicon), M. Cantor (article on von Staudt in Allgemeine deutsche Biographie, vol. 35, 1893), and Encyclopédie (III. 1. 2. p. 207, 1915) refer to only the one edition of (G.).

†On the reverse side is "Druck von E. Th. Jacob in Erlangen." It will be seen later (in connection with Wöckel's Geometrie der Alten) that Korn was probably the successor of Bauer and Raspe.

$\ddagger$ In "Kayser" this date is 1876, which is, according to its catalogue, the date of the copy in the Library of Congress. 
Korn, 1873 and 1876). $\dagger$ In the twelfth edition (published by Korn in 1880 it was increased to 856. On the supposition that Korn kept his advertisements up to date, von Staudt's book must have appeared after Wenz's Atlascommentar of 1877* and before the twelfth edition of Wöckel's Geometrie der Alten in 1880. Its probable date is thus a little before 1880."

Judging by typography, the new editions of (G.) and (B.) were published about the same time.

An entry in the "Katalog des mathematischen Lesezimmers der Universität Göttingen" $\dagger$ suggests that there may have been yet a third German edition of (G.) in 1846, since it has "Nürnberg [1846]" after the title. More probably however it is the edition described above as without date, incorrectly catalogued.

\section{MATHEMATICAL PERIODICALS.}

Union List of Mathematical Periodicals. By D. E. Sмгтн and C. E. Seely. (Bureau of Education, Bulletin 1917, No.

9.) Washington, D. C., 1918. 60 pages. Price 10 cents.

THIS union list is a guide to the location of certain periodicals. The compilers have stated: it was "prepared for the use of research students in mathematics in the universities of the United States. It is not intended to be a complete list of all publications of this kind; indeed, such a catalogue, while very desirable from the bibliographical and historical standpoint, would not ordinarily serve the purposes of the graduate student in mathematics as well as a brief list of this nature. The selection has been made after consultation with a number of professors in those universities that have most to do with directing research work in mathematics in this country, and it represents the periodicals which, in the judgment of these advisers, the students will be most apt to consult in his investigations."

Of about 165 serial publications so selected, somewhat less than one half are wholly mathematical. In connection with

* The number " 850 " occurs in the title from the fourth (1856) to the eleventh editions inclusive.

$\dagger$ Bearbeitet von K. Hiemenz. Mit einem Vorwort von F. Klein. Leipzig, 1907 , p. 92. 